\title{
El teatro y nuestra América
}

\section{Miguel Rubio Zapata*}

Resumen

Aquí se publica el discurso de Miguel Rubio Zapata, director del Grupo Cultural Yuyachkani, en la imposición del Doctorado Honoris Causa en Arte por la Universidad de las Artes (La Habana, Cuba). La ceremonia en su honor se llevó a cabo el 11 de mayo de 2010 y tuvo lugar en la sala Manuel Galich, de Casa de las Américas de La Habana.

Las palabras iniciales fueron de la doctora Raquel Carrió, quien destacó la importancia de Yuyachkani en el contexto del teatro latinoamericano. Asistieron a la ceremonia el Ministro de Cultura de Cuba Abel Prieto; Roberto Fernández Retamar, presidente de Casa de las Américas; Rolando González Patricio, Rector de la Universidad de las Artes; directivos de la Casa, actores del Grupo Cultural Yuyachkani y teatreros cubanos, entre otras personalidades.
Abstract

Here it is published the speech of Miguel Rubio Zapata, director of the Yuyachkani Cultural Group, when he was granted the Honorary Doctorate of Arts from the University of the Arts (Havana, Cuba). The ceremony in his honor was held on May 11, 2010 and took place at the Manuel Galich Room of the Casa de las Americas in Havana.

The opening words were from Dr. Raquel Carrió, who stressed the importance of Yuyachkani in the context of Latin American theater. Attended the ceremony the Cuba Minister of Culture Abel Prieto; Roberto Fernández Retamar, president of the Casa de las Americas; Rolando Patricio González, Rector of the University of the Arts; managers of the Casa, actors of the Yuyachkani Cultural Group and Cuban theater people among other personalities. 
Gracias maestra, compañera y amiga Raquel Carrió por tus generosas palabras. Gracias a la Casa de las Américas y al ISA (Universidad de las Artes, Cuba) por este reconocimiento que comparto con mis compañeros y compañeras de Yuyachkani, compañeros de tiempo de viento y de luz a quienes debo mi aprendizaje. Desde hace cuarenta años soy un observador de su crecimiento, de su autonomía como artistas, autores-actores de su creación. En nombre de cada uno de ellos hago mío este reconocimiento.

Es justo también rendir homenaje desde esta tribuna a los maestros que nos formaron, algunos de ellos sin saberlo, como Luis Valdez y su teatro campesino, de gran inspiración para nosotros, Augusto Boal, Vicente Revuelta, Flora Lauten, Santiago García, Enrique Buenaventura, Oswaldo Dragún, Rosa Luisa Márquez, Antunes Filho, Eugenio Barba, todos ellos viven en nosotros.

En esta, nuestra Casa de las Américas, entendí y sentí que soy latinoamericano y parte de una moderna tradición escénica que surge en nuestra América a mediados del siglo XX. ¿Qué es el teatro latinoamericano ahora? Me ha tocado oír esta pregunta en muchas oportunidades y a veces me he visto obligado a intentar responderla sin tener muy en claro qué decir. $Y$ hoy vuelvo a la pregunta, pues se trata de un interés, de una curiosidad, que por alguna razón persiste.

Tengo la impresión de que a veces solemos afrontar esa pregunta con una verbalización grandilocuente, con cierta actitud cansina que se repite, 0 con medias respuestas dichas como para salir del paso. En otras ocasiones, la respuesta consiste en ignorar la pregunta, pasarla de largo o buscar salidas rápidas. Más allá del silencio como opción o de la fuga ante la pregunta, se suelen oír respuestas dadas por voces que se refieren al tema como algo en vigorosa emergencia, como si nada hubiera cambiado en cincuenta años o, en el otro extremo, presentando al teatro latinoamericano como tema viejo y superado sobre el que tenemos poco o nada qué decir.

Cuando la conversación se orienta hacia estos extremos, el aliento se hace corto y el interés rápidamente se desliza hacia temas considerados como «más actuales», «menos complicados» o el discurso es llevado hacia el campo de la estética o de la técnica (por cierto, separadas de su contexto). Y, claro, sabemos que ha corrido mucha agua bajo el puente, el tiempo no ha pasado en vano y además no vivimos precisamente en tiempos que resistan afirmaciones ligeras o categóricas frente a las situaciones complejas que vivimos. A decir verdad, me siento parte de esa incertidumbre, y de alguna manera hago mío el conflicto de una definición que nos acerque a un sitio que refleje el momento.

Ese lugar, esa patria nueva que hemos llamado «teatro latinoamericano», da señales de insurgencia a mediados del siglo XX. Se trata de un paradigma, un sueño compartido por muchos, una gran ilusión y, también, resultado de la convicción de sabernos parte de una gran revolución teatral que andaba al paso de una gran revolución social que estaba cantada y de la que no teníamos ninguna duda acerca de su posibilidad y de su inminencia. Como todo fenómeno artístico, nuestra práctica vino acompañada de simplificaciones, de voluntarismo, de retórica, etcétera. En medio siglo de historia, los 
fundamentos de eso que llamamos «la moderna tradición del teatro latinoamericano» han pasado por muchos estadios en los que nuestros teatros no han dejado de accionar sobre el contexto y el público de maneras muy diversas. Nuestras dificultades para asumir el activo y el pasivo de esa memoria no debe llevarnos a la pretensión de ser «modernos» incluyendo esto el costo de omitir nuestra historia reciente, como si se pudiera construir lo nuevo omitiendo lo vivido.

Quienes hemos recorrido un trecho más o menos largo de este camino tenemos la obligación de dirigirnos especialmente a los jóvenes insatisfechos con el teatro que heredan, para decirles que algunos de nosotros también lo estamos, que nos hemos cansado de las frases categóricas que afirman o niegan de manera absoluta, para decirles que podemos ser del mundo sin renunciar a nuestra aldea, que Godot tiene parientes que lo esperan en estas tierras, que Antígona tiene aquí tantas hermanas como hijos Madre Coraje y hermanos Arturo Ui, cómo no. El tiempo no ha pasado en vano y los sobrevivientes del teatro latinoamericano hemos sabido relativizar nuestros supuestos, por eso seguimos vivos.

Tenemos que hacer un gran esfuerzo para no enfermarnos de olvido sin que la historia nos pese tanto que nos impida encontrar un equilibrio entre el pasado y el futuro. En ese andar los pesos se han movido, entre una América Latina aparentemente obsesionada en mirar su historia y las particularidades que la hacen distinta en el mundo, y otra Latinoamérica que parece haberse inclinado más bien hacia posiciones en donde prevalece un modelo económico que suscribe una globalización «a cualquier costo», aunque parte del precio a pagar pueda ser el futuro del ser humano. Los teatreros que antes exhibíamos con orgullo el ser parte de este "paraíso exótico» y "cuna de revoluciones», parece que tenemos ahora grandes dificultades para saber quiénes somos y dónde estamos parados.

Me siento un testigo privilegiado por haber vivido de cerca momentos en los que no había ninguna duda sobre el tema y donde se suscribía con orgullo la vitalidad del teatro latinoamericano. He conocido a maestros y grupos protagonistas de esta historia, fundadores de esta moderna tradición teatral sustentada fundamentalmente en colectivos de creación en donde aprendimos a inventar sabiendo que la cultura se gesta en cada momento de la vida. Puedo reconocer características muy concretas que nos hacían semejantes, y al mismo tiempo, diferentes, como son los diversos caminos del teatro en nuestro continente. Con ellos, y gracias a ellos, hemos sabido del impulso de la creación colectiva, del teatro de grupo, y hemos logrado nuevos espacios para la escena.

La irrupción de nuevos personajes, protagonistas de nuevas historias, de nuevos actores, de nuevos espectadores y de nuevos espacios, ha implicado el desarrollo de una dramaturgia nueva y compleja, capaz de contener a tanta diversidad. Se trata de todo un conjunto de señales que nos situaban ante un proceso en el que nos reconocíamos en un entretejido diverso y cargado de matices, como lo son nuestras culturas, y dentro de esa diversidad confluyente pudimos ser testigos y a la vez parte de un movimiento en crecimiento. 
Algunas veces hemos dado motivo para que nuestro teatro se asocie a una postura idílica, ingenua, que asocia identidad con una mirada nostálgica y anclada en el pasado, y cuya consecuencia es una cierta simplificación que ciertamente genera rechazo.

Esto conduce a otra postura no menos extrema que solo encuentra diferencias y por ningún lado semejanzas o factores comunes. Puedo entender que a la base de esta actitud está un rechazo, que comparto, a cierta mirada que asocia teatro latinoamericano a una suerte de expresión menor, vernácula y costumbrista. En los festivales europeos muchos querían ver Macondo en nuestras obras, cuando no sensualidad amazónica o exotismo altiplánico. En la otra orilla, algunos colegas que no encuentran razones suficientes para hablar de teatro latinoamericano prefieren aludir a este como el teatro que se hace en Latinoamérica, así de sencillo y punto. Otros, con el fin de sustentar una teatralidad originaria, prefieren refugiarse en los orígenes prehispánicos, como si fuera posible que la cultura se pudiera mantener inmutable en el tiempo.

Para encontrar los vínculos que nos permitan hablar de un teatro latinoamericano nos corresponde mirar críticamente y con la menor cantidad de prejuicios posible, a nuestra casi olvidada historia reciente. Así podremos ver cómo lo esencial de esa gran fuerza y vitalidad de nuestro teatro fue posible por la gran confluencia sin precedentes de movimientos generados por actores, autores, directores, dramaturgos y artistas procedentes de todas las disciplinas. El grupo fue la célula madre en que nos organizamos para gestar esa nueva teatralidad que reclamábamos a voz en cuello y que debía marchar acorde con los tiempos que se vivían, donde predominaba un sentimiento colectivo. Esto sucedió de manera paralela a otras instancias creativas que dieron señales de fogosa presencia como el llamado boom de la literatura, la danza, el nuevo cine latinoamericana, la fotografía, el documental, las artes plásticas, etcétera. Esto, por cierto, fue un hecho estético y fundamentalmente político que estaba en el marco de un intenso contexto político y social. Los artistas, de manera explícita o no, estaban reflejando la esperanza movilizadora de nuestros pueblos, empeñados en tomar las riendas de su historia. Y allí, al lado de ellos, y no de casualidad, estábamos los teatreros, inventando auroras, como decía una canción popular nicaragüense de la época.

Me doy cuenta de que esa es una historia más o menos conocida para la gente de mi generación, de modo tal que puedo referirme a ella citando algunos episodios para saber de qué estamos hablando cuando el auditorio es contemporáneo a mí. Al mismo tiempo compruebo la dificultad que me produce trasmitir esta memoria a jóvenes estudiantes, quienes de esa historia solo parecen tener un pálido reflejo. Entre ellos campea el desconocimiento de ese periodo no tan lejano. Y, claro, los jóvenes tienen todo el derecho de vivir su presente sin cargar con un pasado que no les corresponde; sin embargo, hay que decir que a las nuevas generaciones alguna curiosidad debiera darles saber qué hicieron sus padres. Conocer les podría ser de utilidad para poder eliminar fantasmas, ubicarse mejor en su presente y seguir trabajando, sin lastres y sin zonas oscuras en la memoria, en el buen teatro que nos mere- 
cemos.

Venimos de tiempos revueltos pero creo que los son más ahora. Intentar una mirada hacia delante implica, desde mi punto de vista, no solamente reconocer en nosotros la posibilidad de imaginar el futuro, de inventarlo, y no solamente aceptar lo que se nos viene como si fuera dado, parte de un orden natural incontestable. Implica también saber de dónde venimos, saber cuál es esa memoria que tenemos guardada sobre aquello que hemos denominado Teatro Latinoamericano, la que ahora aparece como una zona inaprensible y, cuando no, desconocida de nuestra historia, de nuestra biografía artística.

Esto significa también dar una mirada integral que nos permita no solo ver textos y autores, sino también movimientos, desplazamientos. Los espectáculos pueden ser hitos de este reconocimiento, pero al mismo tiempo podemos acercarnos a los procesos creativos, no solo a sus resultados, sino también a los lineamientos pedagógicos. Así podríamos ver cómo todo esto ha operado en nuestra historia reciente.

Si tomáramos como punto de partida la mitad del siglo XX, veríamos un movimiento en proceso, un teatro que se lanza a inventarse, a reconocer sus particularidades como resultado de una grande y rica diversidad cultural, $y$, al mismo tiempo, veríamos nuevos sectores sociales tradicionalmente deprimidos sacando la cabeza como público, como hacedor y copartícipe primordial. No es mi intención hacer un recuento histórico pero sí reclamar la tarea pendiente del rescate y la reconstrucción de una memoria donde concurra de manera integral nuestra historia en todas sus múltiples vertientes.

A mi entender los mejores momentos (si podemos hablar de mejores momentos), o más bien, los momentos de gran fuerza y singularidad en esta historia, han sido aquellos en que nuestro teatro ha sido parte de las luchas de nuestros pueblos por darse una vida mejor. Entonces, en esos momentos, nos atrevimos a reconocernos en nuestra particularidad y a inventar creativamente el teatro que nos hacía falta, sin vernos obligados a marchar al compás de las culturas hegemónicas.

Si con algo esencial me quedo de ese proceso vivido desde mediados del siglo XX es con el ejercicio del teatro como un espacio de creación, pues nuestros viejos maestros nos enseñaron a inventar. Esa ha sido la lección fundamental. Abrirse a la invención es lo que nos ha permitido cambiar y transitar por los caminos más diversos para saber decir y para saber estar en el momento apropiado, para acercarnos a formas genuinas de teatralidad nacidas de la necesidad de comunicar. Ese ha sido el camino que he recorrido con mi grupo Yuyachkani y nuestra historia es un episodio, una pequeña parte de la historia del teatro latinoamericano.

Los impulsos que dieron origen al teatro radical y contestatario de mediados del siglo XX no procedían de ningún esfuerzo voluntarista ni de la operación dialéctica de ideología alguna. Sus raíces, las que lo explican y le han permitido ser, se hunden en la historia y proceden de la necesidad de refutar la imposición política y cultural derivada de la conquista. El teatro europeo fue impuesto desconociendo las formas de la representación que habitaban en estas tierras, las que, en el mejor de los casos fueron señaladas con categorí- 
as occidentales, siendo muchas de ellas proscritas con argumentos teológicos convergentes con las necesidades de la conquista y la dominación.

Durante la conquista y el coloniaje, a la exclusión de los indígenas -cuya condición de seres humanos, incluso, fue puesta en duda por la ideología oficialcorrespondió la exclusión de prácticas artísticas y culturales. Estos últimos procesos no se pueden considerar concluidos aún hoy. En la misión colonial, aquello que no pudo ser erradicado fue incorporado para interiorizar los valores del catolicismo usando para ello los elementos de representación presentes en la danza, la música y la imagen, los que posteriormente van a ser asimilados en los grandes despliegues festivos, iniciándose así niveles de mezcla y sincretismo con los cuales convivimos hoy y los que sustentan el encuentro de elementos prehispánicos y cristianos en una conjunción de ritos de diversa procedencia. Sensibilizarnos sobre cómo opera este mecanismo sincrético es fundamental para entender la mezcla y la hibridización de procesos culturales en constante movimiento.

En el curso de la Colonia, muchas formas de la representación prehispánica asumieron moldes de acuerdo a parámetros del teatro occidental, es decir, los «géneros» oriundos encontrados por la conquista fueron definidos con referencia a un canon cultural español, conllevando esto el despojo de las formas originales y castrando de ellas su esencia de evento efímero, en algunos casos ritual y sagrado. Esta es historia conocida y merece recordarse porque actualmente se siguen desconociendo prácticas escénicas que no corresponden a la hegemonía cultural. Por eso nos parece justo afirmar una teatralidad compleja, que tenga que ver con reconocernos en una identidad inclusiva.

Las formas dramáticas de origen prehispánico son similares a géneros asiáticos como el teatro chino, japonés o hindú, donde, por ejemplo, no existe la separación entre actor y danzante, y donde se privilegia la experiencia de lo que se genera en la escena antes que lo que se narra, lo cual muchas veces es un pretexto sobre el que se entrelazan códigos que componen un tejido complejo. Debemos a Antonin Artaud, Jerzy Grotowski, Peter Brook y Eugenio Barba, entre otros, el haber repensado y ampliado criterios para acceder a otros niveles de entendimiento de las prácticas escénicas. Ellos dirigieron una atenta mirada hacia lo sagrado, lo ritual y lo antropológico, indagaron en culturas originarias de Asia, Africa y América Latina y el Caribe. Esta mirada se nos devuelve como un espejo en cuyo reflejo todavía no nos hemos confrontado de manera suficiente con ese caudaloso imaginario escénico que habita entre nosotros desde los orígenes de nuestra civilización.

El teatro es una construcción cultural que nace de valores determinados de acuerdo a la comunidad donde se genera, respondiendo a relaciones sociales específicas, como lo fueron las que operaron en diferentes momentos de la historia. El teatro que llega de España es el teatro del padre, que vino y se impuso ante el teatro de la madre, el de la América prehispánica, generado en contextos rituales, celebraciones, juego, danza, enmascaramiento. Estas formas siguen vivas y han cruzado el tiempo con una mitología que las sustenta y desde donde se construyen acontecimientos irrepetibles que evocan 
maneras ancestrales de la representación. Las nuevas generaciones no tienen modelos y nuestras fronteras escénicas están saludablemente movidas, hay zonas cada vez más indefinidas y en ellas nuevos espectadores, todo esto situado en un marco cultural expandido y transuniversal.

Se hace necesario que el lenguaje de nuestro oficio no se resista a usar nuevos términos y que podamos ir al encuentro de una teatralidad compleja, que tenga que ver con reconocernos en todos los matices de una identidad inclusiva, donde se encuentren los elementos de una América prehispánica, y en ella lo híbrido, el arte conceptual, el artista objeto y sujeto de su obra, la negación de la representatividad, la intervención de espacios públicos, las ambientaciones, la apropiación de tecnologías, etcétera. Todas estas entradas cobran sentido y son pertinentes como objetos de exploración debido a lo complejo de nuestras sociedades, donde ciudadanía, exclusión, corrupción y racismo son objetos de reclamo permanente. El buen teatro siempre será aquel que funciona en los códigos de su comunidad sin renunciar a esa compleja relación entre lo real y el artificio.

La América Latina y el Caribe no es una sola: es indígena, es africana, es europea y es contemporánea, abierta a todas las prácticas escénicas del siglo XXI; nuestro teatro recorre el espíritu de los tres continentes y se alimenta culturalmente de esas tres raíces y con ellas dialoga en igualdad de condiciones con los teatros de todo el mundo. 